NBER WORKING PAPER SERIES

\title{
THE MAKING OF AN INVESTMENT BANKER: MACROECONOMIC SHOCKS, CAREER CHOICE, AND LIFETIME INCOME
}

\author{
Paul Oyer \\ Working Paper 12059 \\ http://www.nber.org/papers/w12059 \\ NATIONAL BUREAU OF ECONOMIC RESEARCH \\ 1050 Massachusetts Avenue \\ Cambridge, MA 02138 \\ February 2006
}

I thank Ken Corts, Liran Einav, Eric Forister, Dan Kessler, Kathryn Shaw, Andy Skrzypacz, Till von Wachter and Jeff Zwiebel for comments. I thank Ed Lazear for both sharing the MBA survey data and useful suggestions. I am also grateful to Stanford's Vic Menen and Andy Chan and to Wharton's Christopher Morris and Jennifer Sheffler for providing historical placement information for their schools. The views expressed herein are those of the author(s) and do not necessarily reflect the views of the National Bureau of Economic Research.

C2006 by Paul Oyer. All rights reserved. Short sections of text, not to exceed two paragraphs, may be quoted without explicit permission provided that full credit, including $(\odot)$ notice, is given to the source. 
The Making of an Investment Banker: Macroeconomic Shocks, Career Choice, and Lifetime Income

Paul Oyer

NBER Working Paper No. 12059

February 2006

JEL No. M5, J31, J44

\begin{abstract}
New graduates of elite MBA programs flock to Wall Street during bull markets and start their careers elsewhere when the stock market is weak. Given the transferability of MBA skills, it seems likely that any effect of stock returns on MBA placement would be short-lived. In this paper, I use a survey of Stanford MBAs from the classes of 1960 through 1997 to analyze the relationship between the state of the stock market at graduation, initial job placement, and long-term labor market outcomes. Using stock market conditions at graduation as an instrument for first job, I show that there is a strong causal effect of initial placement in investment banking on the likelihood of working on Wall Street anywhere from three to twenty years later. I then measure the investment banking compensation premium relative to other jobs and estimate the additional income generated by an MBA cohort where a higher fraction starts in higher-paid jobs relative to a cohort that starts in lowerpaid areas. The results lead to several conclusions. First, random factors play a large role in determining the industries and incomes of members of this high-skill group. Second, there is a deep pool of potential investment bankers in any given Stanford MBA class. During the time these people are in school, factors beyond their control sort them into or out of banking upon graduation. Finally, industry-specific or task-specific human capital appears to be important for young investment bankers.

Paul Oyer

Graduate School of Business

Stanford University

518 Memorial Way

Stanford, CA 94305-5015

and NBER

pauloyer@stanford.edu
\end{abstract}


"Back in January 1987... Wall Street was booming... When the job offers rolled in, students played one house against another. They were the supply, and the demand was strong... After the crash, the receptions that had once played to packed houses were drawing a few dozen students. Out went the tenderloin on toast and the shrimp; in came the dips and the hot dogs on toothpicks. The school placement office sent out a memo suggesting career 'flexibility' for finance majors like me; we should look into opportunities in manufacturing and consulting." - Brown (1988)

\section{Introduction}

New MBAs take jobs on Wall Street in large numbers during bull markets. When stock market conditions are less favorable, a combination of supply and demand factors make new MBAs less likely to start their careers in the financial sector. Given the transferability of MBA skills and the new MBAs' reputation for job hopping, one might expect people to move in and out of finance jobs such that the long-term labor market outcomes of MBA classes would be similar. In this paper, I analyze the degree to which MBAs' first jobs are driven by the stock market and whether the effects of initial conditions do, in fact, fade quickly with labor market experience.

I use data from a 1996-1998 survey of several thousand Stanford MBAs. The Stanford Graduate School of Business (GSB) alumni provided details on jobs between graduation and the survey, as well as jobs before studying at Stanford. I first show that stock returns while GSB students are in school have a large effect on the fraction of any graduating cohort that starts their careers in investment banking (which, throughout the paper, I define as working for an investment bank, in investment management, or for a venture capital firm.) This effect is substantial for the class as a whole and for those who did not work in investment banking before getting an MBA. But the effect is particularly large for those who worked in investment banking before getting an MBA.

I then show that this effect of conditions at the time of graduation is very persistent. Specifically, I instrument for taking a job in investment banking after graduation with stock returns while the person was attending Stanford. Then I estimate the causal effect of starting in investment banking on working in that industry at any given point later in the person's career. I find that starting in investment banking increases the probability of working there at any given point three to twenty years after graduation by $60-85 \%$. Though it is difficult to be sure that the additional investment bankers created by bull markets would not otherwise have taken jobs similar to those taken by other GSB graduates, I show suggestive evidence that bull markets cause GSB graduates to be less likely to become entrepreneurs or consultants. I also show evidence that the additional investment 
bankers created by bull markets are no less interested in finance and no less likely to stay on Wall Street than other investment bankers. Rather than attracting people with marginal skill or interest to Wall Street, bull markets push people towards a career they are as well suited to as those who need less encouragement to work there. That is, bull markets create long-term investment bankers.

These findings are consistent with a model where there is a large pool of MBAs in any given Stanford class that would make good investment bankers and they are drawn into that field when conditions are favorable. However, they only take the position due to the compensating differential and would be nearly as happy taking a position in another industry. The results also suggest that MBAs develop finance-specific human capital while in school and in their initial years on Wall Street, which explains the persistence of initial sector choice. The empirical results are not consistent with a model where there is significant heterogeneity in MBAs' propensities to be investment bankers and banks have to dig much deeper into this pool when bull markets increase their demand for MBAs.

The final empirical step shows that these effects on career choice have large effects on lifetime labor income. I estimate the effect of macroeconomic cohort effects on the labor market income of various GSB individuals and classes. Though the ability to estimate income differences precisely is limited by the survey design, it is clear that investment bankers earn a substantial premium relative to other GSB alumni. The premium varies from about $60 \%$ for a new MBA on Wall Street relative to one in management consulting to over $300 \%$ for an investment banker fifteen years after leaving Stanford relative to an average alumnus with the same amount of experience in any other industry. Depending on assumptions about discount rates, length of career, and what other jobs people would take if they had not gone to Wall Street, I estimate that a new MBA that goes to Wall Street can expect between $\$ 2$ million and $\$ 6$ million in discounted additional lifetime income (using \$1996) relative to what he would earn if he took a job elsewhere. This premium can be interpreted in various ways, but may simply reflect the disutility associated with working in investment banking relative to other fields.

An example of the "experiment" in this paper may help motivate the exercise. Members of the Stanford MBA classes of 1988 and 1989, all of whom were in school during the stock market crash of the Fall of 1987, were unlikely to take jobs on Wall Street relative to other classes. During the long bull market that started a few years later, new MBAs returned to Wall Street in large numbers. But few members of the classes of 1988 and 1989 moved into investment banking. Also, though unusually large numbers of Stanford MBAs from mid-1980's classes went to Wall Street, there is no evidence that these graduates were less interested in (or committed to) Wall Street careers than those smaller groups that went to Wall Street during the bear market. This suggests that many members of the 
classes of 1988 and 1989 had significantly lower lifetime income (though not necessarily lower utility) due to the timing of their graduation. Depending again on assumptions about career length and the like, I estimate that stock return patterns between 1984 and 1989 transferred $\$ 120$ million to $\$ 300$ million of discounted lifetime labor market income from the Stanford classes of 1988 and 1989 to the classes of 1986 and 1987.

There have been numerous prior studies of how macroeconomic conditions when people enter the labor market affect their long-term outcomes. Typically, these papers study large samples of people across a large set of occupations. Two potential weaknesses of these studies are that many employees transition slowly into the labor force, making it difficult to isolate a single "entry" point, and that the average effects in these large samples may mask interesting differences across professions. I try to get around these issues by looking at a group of graduates who enter the labor market at a predictable (and, as I argue in the analysis, exogenous) time. While Stanford MBAs are surely not representative of the economy as a whole, they provide a useful example of high-skilled "knowledge" workers.

Two recent examples from the literature on cohort effects using larger samples are Oreopoulos, von Wachter and Heisz (2005) and Kahn (2005). Oreopoulos et al. (2005) look at the early careers of Canadian college graduates. They find that graduating in a recession lowers wages early in employees' careers, though it does not have a noticeable effect on employment. In their sample, wage differences fade over the first ten years or so after graduation as those who graduated in recessions move from small, low-paying firms to larger firms (and firms in higher-pay industries) when the economy recovers. Kahn (2005) uses the National Longitudinal Survey of Youth to study U.S. college graduates in the classes of 1979-1988. She finds that macroeconomic conditions have important wage effects (which are more persistent than those found by Oreopoulos et al. (2005)). Consistent with the findings in this paper, she attributes the long-term effects to the types of jobs (occupations) where graduates start.

Other papers that look at the relationship between pay and macroeconomic conditions when jobs start include Beaudry and DiNardo (1991), Devereaux (2004), and Baker, Gibbs and Holmstrom (1994). Beaudry and DiNardo (1991) find that macroeconomic conditions at the time an employee starts a job are related to wages, but that this relationship goes away when controlling for the most favorable economic conditions (that is, the lowest unemployment rate) during the job spell. Devereaux (2004) finds that workers who accept low-paying jobs are stuck with low wages for at least several years, relative to observably equivalent workers. Those who switch jobs undo some of the ill effects of starting a job at the "wrong" time, but not all. Baker et al. (1994) examine a single firm. They find that pay differs for cohorts hired at different times and that these differences 
are persistent.

Oyer (2005) looks at the importance of getting a "good" first job for another set of highly skilled professionals $-\mathrm{PhD}$ economists. He shows that the sector of initial job placement (top research institution, teaching institution, private sector, etc.) has a causal effect on the sector of later job placement. He also shows first placement at higher ranked research institutions leads people to be more productive in terms of research output. Oyer (2005) and this paper both use the state of the economy when professionals initially enter the labor market as an instrument for initial job placement. Together, the papers lead to the conclusion that luck early in one's career has important long-term effects on the sectors where many high-skill and highly paid people work, even in labor markets where one might expect people to move relatively freely between firms.

Though they comprise a large and growing segment of the labor market, there are surprisingly few studies using micro-data focused on MBAs. Lazear (2005) and Hvide (2005), both of whom use the same MBA dataset I use, focus on the decision to become an entrepreneur. Reder (1978) and Tracy and Waldfogel (1997) study the determinants of starting salaries for newly graduated MBA's. I know of no prior academic studies that study compensation of MBAs beyond starting salaries. $^{1}$

The rest of the paper proceeds as follows. The next section lays out the theoretical background for why initial placement might have long-term implications. Section 3 describes the data and Section 4 analyzes how initial MBA placement is affected by stock returns. Section 5 documents a causal effect of initial MBA placement on Wall Street on the likelihood of working there as the person's career develops. Section 6 estimates the amount of discounted lifetime labor market income that exogenous shifts into or out of Wall Street careers create for affected individuals and for MBA cohorts as a whole. Section 7 concludes with a summary and suggestions for future research.

\section{Theoretical Background}

Consider a labor market with two sectors, the Financial (" $f$ ") sector and the General (" $g$ ") sector. Assume that, subject to expending some search effort, any MBA can find employment in either of these two sectors immediately after graduation. Then, as the person graduates, he compares the

\footnotetext{
${ }^{1}$ There have been several academic studies of careers in a segment of what I define to be investment bankers - mutual fund managers. Chevalier and Ellison (1999), for example, show that long-term career concerns affect mutual fund manager behavior. Brown, Harlow and Starks (1996) and Chevalier and Ellison (1997) analyze potential conflicts of interest between investors and mutual fund managers. See Chen and Ritter (1995), Gompers and Lerner (1999), Lin and McNichols (1998), and Michaely and Womack (1999), among others, for studies of the fees charged by investment firms and potential conflicts of interest within these firms. These papers do not study pay of individuals, however. See Stewart (1993) for an interesting discussion of the allocation of compensation at one investment bank.
} 
expected utility streams from each of these sectors over the course of his future career. Let $u^{f}\left(w_{f}^{0}\right)$ be the expected utility, as of career year 0 (that is, upon graduation), of a career that starts in the finance sector. The function captures the person's disutility of effort in the financial sector. The $w$ term captures the income stream he can expect from a career that starts in that sector. ${ }^{2}$ The person may have various options (either offers from multiple firms or a choice among the various functions within an investment bank) within the financial sector, but this utility function captures expectations about the job he believes to have the highest expected utility of his options in this sector. Similarly, let $u^{g}\left(w_{g}^{0}\right)$ be the expected utility from his best option in the general sector.

Naturally, the person will start in the financial sector if $u^{f}\left(w_{f}^{0}\right)>u^{g}\left(w_{g}^{0}\right)$. If all graduating MBAs were alike in terms of skill and preferences, then either all workers would go to one sector or the wage differential would make employees exactly indifferent between the two sectors and people would sort randomly. In reality, skills and preferences differ and people sort between the two sectors based on this heterogeneity (as in Jovanovic (1979), Miller (1984), or McCall (1990).) As a result of this heterogeneity, though the marginal graduate is indifferent between the two sectors, some (perhaps nearly all) graduates expect to strictly prefer the sector they choose.

Though expected income streams in the two sectors may be correlated for any given cohort of MBA graduates, the state of the stock market is likely to have a larger marginal effect on expectations about $w_{f}^{0}$ than income in the general sector. This is because favorable conditions on Wall Street will increase demand for labor and, at least, short-term expected pay. Also, under the standard assumption that stock returns follow a random walk, any short-term change in stock market conditions should increase long-term expectations about the level of stock prices. ${ }^{3}$ Therefore, given that a bull market will increase $u^{f}\left(w_{f}^{0}\right)$ relative to $u^{g}\left(w_{g}^{0}\right)$ for some MBAs (and not decrease it for any), it would not be a surprise to find that more people choose jobs in the financial sector in classes that graduate when stock prices and returns are relatively high.

The question of interest, however, is whether this initial effect of a bull market on industry choice is persistent. At year $t$, a person who took a job in the financial sector upon graduation faces expected utility from staying in the financial sector of $u^{f}\left(w_{f}^{t}\right)$. He can also switch to the general sector where he can expect utility of $u^{g}\left(w_{g}^{t}\right)$. There are reasons to expect that, if $u^{f}\left(w_{f}^{0}\right)>u^{g}\left(w_{g}^{0}\right)$, then $u^{f}\left(w_{f}^{t}\right)$ will be greater than $u^{g}\left(w_{g}^{t}\right)$. That is, people who show an initial preference for the financial sector are likely to find the work there relatively pleasant and one would expect that to

\footnotetext{
${ }^{2}$ The person can change sectors. So, $w$ reflects the income in both sectors and the person's expected probability of working in each sector at any given time in the future.

${ }^{3}$ Also, if MBAs make career decisions assuming momentum in stock prices (which would be consistent with the retirement allocations studied by Benartzi (2001)), then high stock returns would encourage them to be more inclined to take a job on Wall Street.
} 
be the case later. There are three underlying models (or classes of model) that would predict those who start in the financial sector are more likely to work there later on, each of which has distinct empirical predictions:

Model 1 - Worker Heterogeneity: Suppose employees differ in "type", as in the Spence (1973) signaling model. Specifically, suppose that there are two types of people who are interested in starting their careers in investment banking. The first type, "bankers", will be highly productive investment bankers because their skills match the production function well. "Non-bankers" have a high marginal utility for money (and so seek the highest paying job possible no matter their skills.) When times are lean on Wall Street, the second type shows less interest in working there (that is, the expected value of $w_{f}$ is lower so they consider alternatives.) When conditions improve, banking firms are reluctant to hire those who did not start their careers on Wall Street because they have revealed themselves to be unproductive investment bankers. But, when hiring new MBAs, they have no method for separating the productive bankers from the non-bankers. After some time working on Wall Street, the non-bankers are revealed (after a period of enjoying a high income) and they are either fired or choose to move to the general sector. This model predicts that bankers end up in banking and non-bankers do not, no matter when they enter the market. Therefore, though it implies that there would be a correlation between between starting in banking and working there subsequently, there is no causal effect of first job on subsequent jobs..

Model 2 - Homogeneous workers with Investment-Banking Specific Human Capital: Suppose there is a large pool of MBAs that would be productive investment bankers. ${ }^{4}$ Much of this pool is nearly indifferent between the two sectors, given the expected income differences over time. However, anticipating opportunities in banking, those who go to school during bull markets develop Wall-Street-specific human capital both in school and at the beginning of their post-graduation careers.

To be a little more concrete, consider the model in Gibbons and Waldman (2006). They model "task-specific human capital" and show that it can lead to long-term effects of initial job placement on the types of jobs workers hold. In their model, those hired under favorable conditions are initially given high value tasks and develop more valuable human capital that persists throughout their careers. A similar idea, industry-specific human capital, has been shown to be important in the labor market generally (see, for example, Parent (2000)) and it is often cited as a primary reason that wage losses can be quite high for displaced workers (see Neal (1995).) Therefore, financespecific skill may widen the gap between $w_{f}^{t}$ and $w_{g}^{t}$ as a career in the financial sector continues

\footnotetext{
${ }^{4}$ This group need not be the entire MBA class, but enough to meet hiring demands during bull markets.
} 
(that is, as $t$ increases. $)^{5}$

Finance-specific human capital would lead those who go to Wall Street to be relatively productive there and would lead to a causal link between starting a career on Wall Street and working there later on. Homogeneity implies that those who go to Wall Street during bull markets would not be noticeably different from those who go to Wall Street during bear markets. As a result, even though the entering pool of bankers would be larger in bull markets, they would not be any less prone to success in banking than those who choose to go to Wall Street during a bear market (in stark contrast to Model 1.) This would lead to the empirical prediction that those hired during bear markets would be as likely to stay in investment banking as those hired in bull markets and that those hired in bull markets would be no less able (in terms of finance training and interest) than those hired in bear markets.

Model 3 - Some Heterogeneity and Some Specific Human Capital ("Hybrid Model"): It seems unlikely that the world is as stark as either of the two models just sketched. So consider a world where there is heterogeneity in how well MBAs are suited to work in banking and where bankers develop Wall-Street-specific capital. During bull markets, increased demand for MBAs would lead to the marginal hire being less fit for a career in banking. However, because these lower-fit bankers develop finance-specific human capital, at least some of them stay because their specific capital makes them better bankers than new graduates who are naturally better fits. That is, like Model 2, the hybrid model makes the empirical prediction that specific human capital will cause those who start their careers on Wall Street to be more likely to work there later on, even controlling for ability or fit. However, unlike Model 2, given sufficient heterogeneity, banks would replace the worst fits hired in a bull market with the best fits available during a bear market. This distinction leads to the prediction that new MBAs who go to Wall Street during bull markets will be, on average, less fit for careers in banking than new bankers who graduate in bear markets.

In the sections that follow, I investigate the predictions of these three models. First, I show that new MBAs are more likely to go to Wall Street during bull markets, which is an important assumption of each model. Second, I show that those who go from Stanford Business School directly to Wall Street are more likely to work on Wall Street later in their careers, which is consistent with each of the models. Then, using Wall Street conditions while MBAs are in school as an instrument

\footnotetext{
${ }^{5}$ While I will discuss specific human capital as though it is a productivity investment, it could simply be the result of lower transaction costs. For example, models where incumbent firms have more information about an individual than other potential employers (such as Akerlof (1970) and Waldman (1984)) or pure search cost models would lead to "stickiness" in choice of industry. The cost of search, any cost of switching industries, or aversion to the risk of unknown features of the general sector will lower $u_{t}^{g}\left(w_{g}\right)$ for any employee in the financial sector in the same way that specific finance skills raise $u_{t}^{f}\left(w_{f}\right)$. Another related alternative with the same implications is that, as workers get accustomed to a job, the disutility of effort may decline.
} 
for first job, I show that the link between initial placement and later employment on Wall Street is causal in the sense that an MBA who starts on Wall Street is more likely to work there later because he started his career there. I also show evidence that suggests that those who take jobs on Wall Street after graduating in bull markets are no less interested or tied to Wall Street As I explain in Section 5.2, the evidence suggests that random factors play an important long-term role in MBA careers and that model 2 most closely matches the patterns in the data. I then go on to measure the magnitude of the effects of these random shocks.

\section{Data}

The data is based on a mail survey of Stanford Graduate School of Business (GSB) Alumni. The survey was conducted in 1996 and 1998 and had a response rate of approximately 40\%. Survey respondents provided detailed job histories, including jobs before they entered Stanford's MBA program. I use information gathered from members of the GSB classes of 1960 through 1995. I dropped any job where the person worked less than half time. If the person reported two jobs simultaneously, I use the one which he reports working more hours. If the hours are the same, I use the job where salary information is available.

Table 1 provides summary statistics of all post-graduation person/year observations, as well as details on each person's job the year after graduation and at the time of the survey. Observations in this table and throughout the analysis are a snapshot of the person's job as of the end of January of each year. ${ }^{6}$

Respondents also provided details on the industries where they worked. I define investment banking (or, in some tables and figures "I-bank") broadly to include investment banking, investment management, and venture capital. The final column of Table 1 provides information about all person/year observations within this industry. Men and non-minorities are slightly over-represented in this group. Investment banking has become more common over time. However, as will become clear below, the fraction in investment banking does not change noticeably with age or years of experience (unlike, for example, management consulting, which is much more likely to be a first job than a job held later in a career.) The investment bankers as a whole are somewhat more likely to have founded the business where they work than the rest of the sample. This is because venture

\footnotetext{
${ }^{6}$ Columns 1 and 4 include all relevant person/year observations for a given person while the middle columns include at most one observation per person. Because older people have, on average, more years of data, the data in columns 1 and 4 are weighted towards earlier graduates. Column 2 does not include people who were unemployed in the January after graduation and Column 3 does not include those who were unemployed (usually due to retirement) at the time of the survey.
} 


\begin{tabular}{lllll}
\hline \hline & Total & First Job & Survey Job & I-bank Jobs \\
\hline Female & $11.6 \%$ & $19.3 \%$ & $19.0 \%$ & $10.4 \%$ \\
Work in USA & $86.1 \%$ & $83.2 \%$ & $83.2 \%$ & $86.6 \%$ \\
Minority & $7.3 \%$ & $12.2 \%$ & $11.9 \%$ & $6.8 \%$ \\
Investment Banking & $14.5 \%$ & $14.2 \%$ & $18.3 \%$ & $100 \%$ \\
Consulting & $10.7 \%$ & $18.6 \%$ & $13.6 \%$ & $0 \%$ \\
High Technology & $10.6 \%$ & $10.9 \%$ & $12.0 \%$ & $0 \%$ \\
Partner/Owner & $24.9 \%$ & $7.6 \%$ & $31.4 \%$ & $33.8 \%$ \\
Founder & $11.4 \%$ & $2.9 \%$ & $15.9 \%$ & $13.6 \%$ \\
Employees (median) & 1,000 & 2,000 & 450 & 500 \\
Salary > $\$ 50,000$ & $77.8 \%$ & $41.4 \%$ & $93.4 \%$ & $89.5 \%$ \\
Salary > \$100,000 & $47.8 \%$ & $5.6 \%$ & $71.3 \%$ & $76.1 \%$ \\
Salary > \$500,000 & $9.0 \%$ & $0.1 \%$ & $13.7 \%$ & $31.5 \%$ \\
Graduation Year & 1973.5 & 1980.4 & 1980.1 & 1975.5 \\
Age & 39.6 & 29.4 & 44.4 & 39.1 \\
Total Person/years & 62,115 & 3,782 & 3,886 & 8,844 \\
\hline
\end{tabular}

Table 1: MBA Sample Summary Statistics. "First Job" is the job the person held in the January after graduating. "Survey Job" is the job held when answering the survey in 1996 or 1998. "I-bank Jobs" is the subset of column 1 person/years where the respondent was employed for an investment bank, a money manager, or a a venture capital firm. "Employees" is the number of employees at the firm where the respondent worked.

capitalists and money managers are much more likely to be founders, while those who work for investment banks are less than half as likely as the rest of the sample to be founders.

The usefulness of the income data is limited in three ways. First, the survey asked people their salaries. Individuals may have interpreted this question differently, with some including bonuses and the value of equity. But the reported numbers are likely understatements of labor market earnings as a whole. Second, the survey asked for the beginning and ending (or current, if the person holds the job at the time of the survey) salary on each job. Therefore, I cannot create a dataset with person/year income information. I primarily rely on the cross-section of income information at the time of the survey. Finally, the survey provided categorical answers to the income questions. Respondents could either say that the relevant salary was under $\$ 50,000$, between $\$ 50 \mathrm{~K}$ and $\$ 75 \mathrm{~K}$, between $\$ 75 \mathrm{~K}$ and $\$ 100 \mathrm{~K}$, between $\$ 100 \mathrm{~K}$ and $\$ 150 \mathrm{~K}$, between $\$ 150 \mathrm{~K}$ and $\$ 200 \mathrm{~K}$, between $\$ 200 \mathrm{~K}$ and $\$ 300 \mathrm{~K}$, between $\$ 300 \mathrm{~K}$ and $\$ 400 \mathrm{~K}$, between $\$ 400 \mathrm{~K}$ and $\$ 500 \mathrm{~K}$, between $\$ 500 \mathrm{~K}$ and $\$ 750 \mathrm{~K}$, between $\$ 750 \mathrm{~K}$ and $\$ 1$ million, between $\$ 1$ million and $\$ 2$ million, and over $\$ 2$ million. In the analysis that follows, I assume the person's income is the mid-point of the reported range and that it is $\$ 3$ million if the person reports income greater than $\$ 2$ million.

Despite these limitations, there are two indications that the data are reasonably accurate. First of all, the average starting salaries for the class of 1995 reported by the Stanford GSB career office 
is approximately equal to the average I calculated from the survey. Retrospective salary data may not be as accurate, but I only use the wages reported at the time of the survey. Second, the fraction of each class that the GSB career office reported taking an initial job in investment banking closely tracks the fraction of each class that I calculated using retrospective job information. For the GSB classes of 1976-1994 (the classes for which I have information from both the career office and the survey), the correlation between the fraction of the class starting in investment banking based on my calculations and on surveys by the career office at the time of graduation is 0.84 . Given that both surveys were voluntary and the industry choices varied from year-to-year in the career office survey, this is a very high correlation.

To get a sense of the dynamics of movement between industries for the respondents, Table 2 shows transitions into and out of investment banking for the first 14 years after graduating. Graduates are listed as moving into investment banking in year 1 if they worked in the industry right after graduation but had never worked in that industry before getting an MBA. Those who move out of the industry in year 1 worked there at some point before school but did not take a job in the industry upon receiving an MBA. In subsequent years, movement in or out simply indicates that the person switched industries during the year.

In the first few years after receiving MBAs, 5-10\% of the people in investment banking leave or were not in the industry the year before. Movement slows after about year five. Movement into the industry is somewhat higher than exit in the first few years after graduation, but the fraction of a typical graduating class that works in investment banking does not change sharply as time progresses.

Aside from the GSB survey, I also use macroeconomic data and data on the initial placement of MBAs graduating from the University of Pennsylvania's Wharton School. I define the 2-year $\mathrm{S} \& \mathrm{P}$ return for a given MBA class as the percentage change in the $\mathrm{S} \& \mathrm{P} 500$ in the two-year period through the end of June when the person graduates. This measure has the nice feature that, with very few exceptions, it is fully determined during the period after the person has decided to enter Stanford's MBA program. Though it is currently common for MBA students to accept offers well before the actual graduation date, I focus on classes graduating in 1995 and earlier when recruiting season ran closer to graduation. I also measure the unemployment rate as of June of the year of graduation. For the Wharton classes of 1973 and later, I define a variable that is the fraction of each class that went into investment banking. This information is based on surveys of each graduating class done by Wharton's career office. ${ }^{7}$

\footnotetext{
${ }^{7}$ Because Wharton changed the way it reported (and, perhaps, the way it calculated) the fraction going into investment banking starting with the class of 1984, I include a "class of 1984 or later" indicator variable in any
} 


\begin{tabular}{lcccc}
\hline \hline Post-MBA Year & Sample & I-bank & I-bank in & I-bank out \\
\hline 1 & 3,754 & 533 & 362 & 173 \\
2 & 3,613 & 512 & 32 & 18 \\
3 & 3,459 & 493 & 46 & 26 \\
4 & 3,326 & 489 & 46 & 17 \\
5 & 3,143 & 486 & 52 & 28 \\
6 & 3,005 & 471 & 27 & 21 \\
7 & 2,877 & 445 & 27 & 23 \\
8 & 2,723 & 425 & 24 & 15 \\
9 & 2,584 & 398 & 20 & 20 \\
10 & 2,475 & 380 & 19 & 13 \\
11 & 2,371 & 356 & 13 & 16 \\
12 & 2,264 & 333 & 16 & 15 \\
13 & 2,156 & 305 & 15 & 11 \\
14 & 2,061 & 291 & 17 & 6 \\
\hline
\end{tabular}

Table 2: MBA Transitions. "I-Bank" is the total number of people working at an investment bank, money manager, or venture capital firm. The "in" column lists the number of people who moved to the relevant type of firm a given number of years after receiving MBAs and "out" column lists the number who moved out of the type of firm. Year 1 in/out refers to change relative to pre-MBA job. Sample size changes because the last observation for a given person is the year of the survey (1996 or 1998).

\section{Initial Job Placement}

Figure 1 shows how the fraction of graduates whose initial placement is at an investment bank (normalized to one for the class of 1994) rises and falls with the two-year return on the S\&P 500 as of June of the year of graduation. The graph shows that the fraction of graduates taking jobs on Wall Street is at least somewhat responsive to recent stock market returns. The graph shows that graduates went to Wall Street in large numbers as the market boomed in the mid-1980's. But, after the market crash of 1987, there was a noticeable drop in the fraction of graduates going to Wall Street. This fraction dropped again during the recession (and weak stock market) of the early 1990's. ${ }^{8}$

One potential problem with interpreting Figure 1 would be if people who wanted to work in investment banking somehow timed the market. Also, if there were predictable cycles in Wall Street hiring and the market, then one might worry that a cohort's interest is correlated with stock returns rather than their first position being driven by it. If the stock market is anywhere close

\footnotetext{
analysis where I use the Wharton career data.

${ }^{8}$ Details on the initial placement of Stanford MBAs from the classes of 1997-2005, including industry and compensation details, can be found at http://www.gsb.stanford.edu/cmc/reports/index.html.
} 


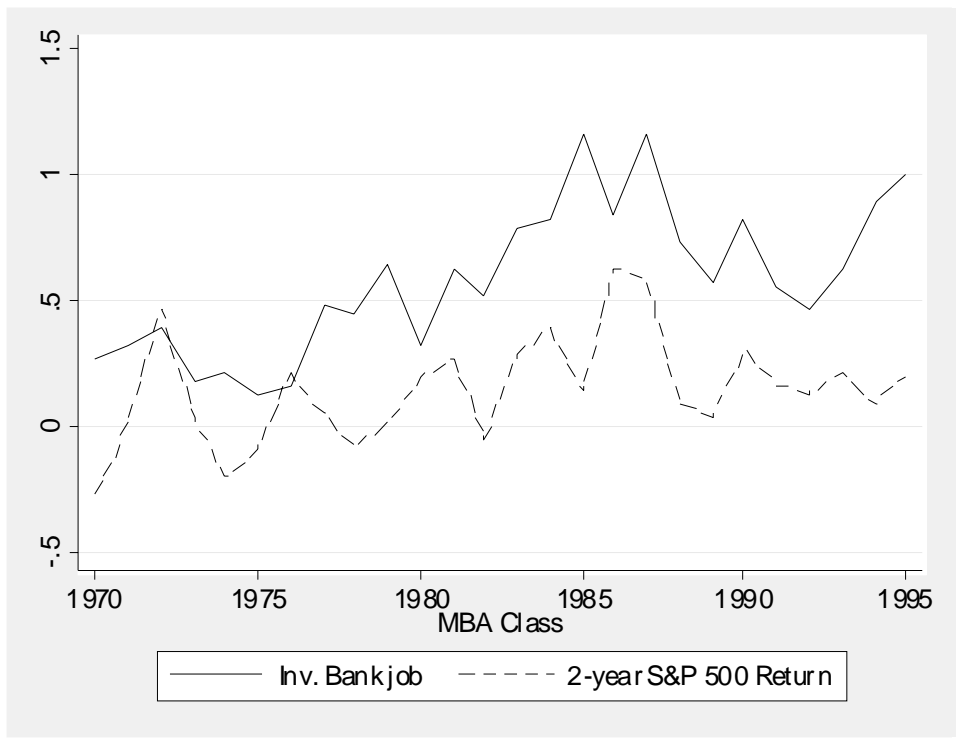

Figure 1: Stock Returns During School and Investment Banking Job Placement

to "perfect" and a random walk, then this concern is not an issue. Nevertheless, I deal with this potential issue in several ways. First, throughout the analysis below, I will control for pre-MBA investment bank experience when looking at post-MBA job selection. Second, consider Figure 2, which shows the relationship between the fraction of an MBA cohort that worked in investment banking before school and stock returns while the cohort was in school. The graph shows that there has been a gradual trend up in terms of the fraction of pre-MBA investment bankers. But the year-to-year changes in the two lines are generally unrelated, with the possible exception that many investment bankers returned to school when the market crashed in 1987.

While these figures provide evidence that there is a relationship between stock returns while students are in school and their first job, I will now be more precise in investigating this relationship as it forms the first-stage of the instrumental variables analyses that follow. Define $F_{i t}$ to be an indicator for whether person $i$ who enters the job market in year $t$ starts his career in investment banking. Following the notation in Section $2, F_{i t}=1$ if $u_{0}^{f}\left(w_{f}\right)>u_{0}^{g}\left(w_{g}\right) . F_{i t}$ is observable in the survey data, so I estimate logistic regressions of the form

$$
F_{i t}=G\left(\theta_{t}, X_{i t}, \Psi_{i}\right)
$$

where $\theta_{t}$ is a measure of demand for MBAs in investment banking in year $t, X$ is a vector of observable characteristics (linear, quadratic, and third-power time trends, gender, and ethnicity), 


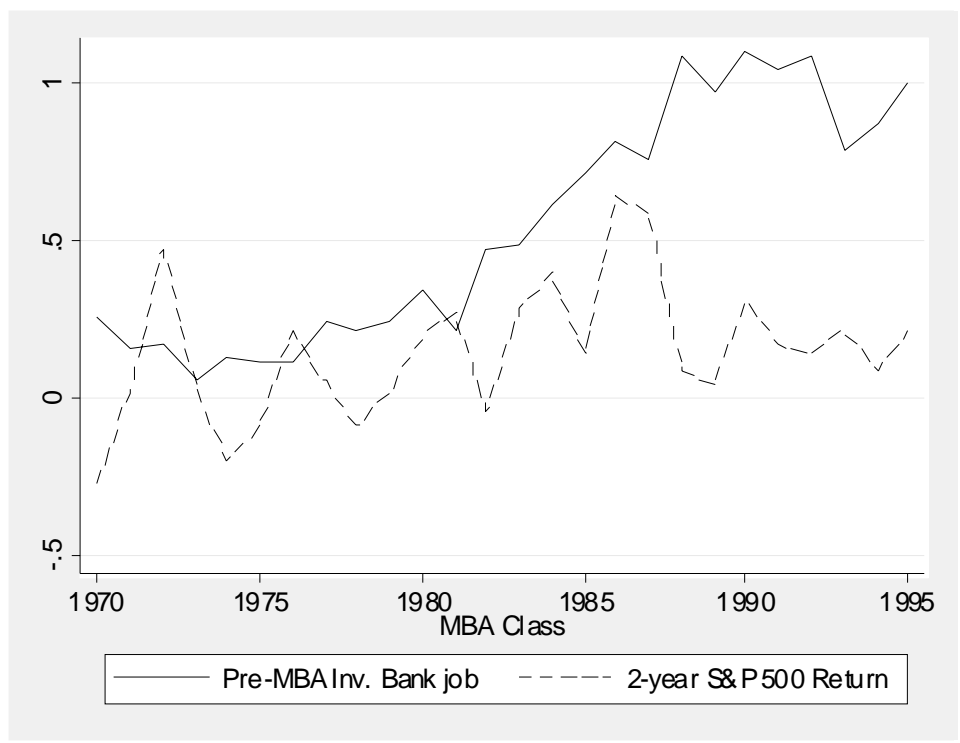

Figure 2: Stock Returns and Pre-MBA Employment

and $\Psi_{i}$ includes unobservable individual characteristics that affect the demand by investment banks for the person's services and the person's preferences for working in investment banking relative to other industries. The main measure of market demand $(\theta)$ is the two-year S\&P 500 return through the end of June of the year the person graduates, but I also use the one-year return ending at the same time, the national unemployment as of the same June, and the fraction of the relevant graduating class from Wharton that initially placed in investment banking. ${ }^{9}$

The results are shown in Table $3 .{ }^{10}$ Column 1 establishes the basic relationship between stock returns and MBA placement. It shows that, in a year when the S\&P 500 increases by $18.5 \%$ (one standard deviation) relative to another year, a typical Stanford graduate's probability of entering investment banking increases by about two percentage points. Given a base probability of 14\%, this means that a one standard deviation increase in stock returns increases initial investment bank employment likelihood by about one seventh. While the state of the stock market is certainly not the only factor that determines whether a person works in investment banking or not, it is an important predictor.

\footnotetext{
${ }^{9}$ The measures of $\theta$ do not vary within a graduating class, so all standard errors are clustered at the class level. I also tried the analysis taking the more conservative approach of averaging at the graduating class level. This did not alter any of the conclusions that follow.

${ }^{10}$ Table 3 displays the results of logistic regressions that are basically the first-stage regressions in IV analyses below. In that analysis, I actually use linear probability models. The results (in terms of the significance of the estimates and the marginal effects of the coefficients) are nearly identical.
} 


\begin{tabular}{lcccccc}
\hline \hline & $(1)$ & $(2)$ & $(3)$ & $(4)$ & $(5)$ & $(6)$ \\
\hline 2-year S\&P return & 0.0991 & 0.1026 & 0.0851 & 0.3055 & & -0.0044 \\
& $(0.0309)$ & $(0.0331)$ & $(0.0335)$ & $(0.1098)$ & & $(0.0642)$ \\
Pre-MBA I-bank & & 0.2026 & Dropped & Others & 0.2366 & 0.2356 \\
& & $(0.0139)$ & & Dropped & $(0.0183)$ & $(0.0183)$ \\
Wharton I-bank & & & & & 0.5697 & 0.5642 \\
& & & & & $(0.1757)$ & $(0.1613)$ \\
Unemployment & & & & & & -0.0121 \\
& & & & & & $0.0062)$ \\
1-year S\&P return & & & & & & 0.0474 \\
& & & & & & \\
Pseudo $R^{2}$ & 0.0442 & 0.1178 & 0.0257 & 0.0421 & 0.1278 & 0.1293 \\
N (People) & 3,547 & 3,547 & 3,230 & 317 & 2,410 & 2,410 \\
\hline
\end{tabular}

Table 3: Initial Placement in Investment Banking. Coefficients are marginal effects on probability, using a logit, where the dependent variables are indicators for the person being employed in investment banking (including money management and venture capital) as of the January after graduation. Each regression also controls for gender, ethnicity (through indicators for Black, Hispanic, and Asian), year, year squared, and year to the third. "Pre-MBA I-bank" equals one if, before starting MBA studies, the person ever worked in investment banking. "Wharton I-bank" is the fraction of graduating Wharton MBAs that took jobs in investment banking in a the year the Stanford MBA graduated. It is only available for the class of 1975 and later, so the sample size is smaller. Unemployment is the national average unemployment rate as of June of the year the person graduated. The S\&P returns are through June of the year the person graduated. Standard errors (in parentheses) are adjusted for any correlation within graduating class. 
Column 2 shows that those who worked in banking before getting an MBA are much more likely than other students to work in investment banking immediately after graduating but that controlling for pre-MBA industry does not change the relationship between stock returns and first job. Column 3 limits the sample to those who did not work in banking before getting an MBA and shows a similar effect of stock returns on first job. This is not surprising, given that over $90 \%$ of the sample in columns 1 and 2 is also in the column 3 sample.

Column 4 limits the sample to the nine percent of the sample that worked for an investment bank before entering the Stanford GSB. The estimated effect of stock returns on this sample is noticeably larger than for the broader sample. A one standard deviation increase in the S\&P 500 return increases the probability of one of these graduates returning to investment banking by about six percentage points. This difference compared to the full sample is to be expected for at least two reasons. First, the unconditional probability of this group going back to investment banking immediately after graduation is about $50 \%$. So the increase of six percentage points is about the same proportionately as the two percentage points for the larger sample. Second, a typical Stanford GSB class includes a large fraction of people that would not seriously consider seeking a job in investment banking. For these people, $u^{f}\left(w_{f}^{0}\right)$ is always less than $u^{g}\left(w_{g}^{0}\right)$, no matter what the level of $\theta_{t}$. These people attenuate any effect of $\theta$ in columns 1-3 of Table 3.

Column 5 shows the relationship between Stanford MBAs going to Wall Street and Wharton MBAs going to Wall Street. The sample size is smaller because the Wharton placement data is only available for the classes of 1975 and later. There is clearly a very strong correlation between the fraction of graduating MBAs from the two schools that go to Wall Street. As one might expect, when there is more Wall Street demand for Stanford MBAs and/or Stanford MBAs are more interested in Wall Street, the same holds for Wharton MBAs.

Finally, column 6 shows that is worth controlling for more than just the two-year return. The positive coefficient on the one-year return suggests that, while stock returns at any point while the person is in school matter, returns in the second year of the program may matter more. Also, when unemployment is high, employment on Wall Street is less common. I use all three macroeconomic explanatory variables in column 6 as instruments for taking an initial job in investment banking.

In addition to the explanatory variables in Table 3, I will also instrument for initial job choice with a set of indicator variables for each graduating class. This allows the first stage to be estimated less parametrically than the estimates in Table 3, which is advantageous because the class indicators explain quite a bit more variation than the variables used in the Table. By way of comparison, the pseudo- $R^{2}$ in a logit with indicators for each class is $13 \%$, or more than three times the level in column 1 . The $R^{2}$ statistics for parallel linear probability regressions are similar to the logit 
pseudo- $R^{2}$.

Given that the fraction of a class that goes to Wall Street fluctuates significantly from year to year, it might seem reasonable to think that there are important differences in the types of MBAs that go to Wall Street in good times and in bad times. Bull markets attract many extra students to Wall Street and one might expect these "marginal" graduates to be less interested in finance than those who go to Wall Street when times are leaner. That is, assuming bull markets raise all students' estimates of $u^{f}\left(w_{f}^{0}\right)$, both models 1 and 3 in Section 2 suggest that the marginal student for whom $u^{f}\left(w_{f}^{0}\right)$ roughly equals $u^{g}\left(w_{g}^{0}\right)$ will be less of a natural fit for a Wall Street career. To investigate this idea, I matched survey responses by members of the classes of 1984-1995 with the classes they took as students at Stanford GSB. Given that the available data only includes twelve years, the macroeconomic variation is not as great as one might hope and I will not present formal analyses. However, it appears that students who went to school during strong stock markets took more finance classes and that this is especially true among those who went on to be investment bankers. Finance enrollments dropped dramatically after the Fall of 1987 stock market crash. While the data do not allow a great deal of statistical precision, it is clearly NOT the case that those who went to Wall Street during the bull markets of the mid-1980's and early 1990's were less prepared for finance careers than those that went to Wall Street in the bear markets of 1988-1989 and 1993-1994.

In summary, stock returns while Stanford MBAs are in school has a statistically and econom-

ically significant effect on the likelihood that they work in investment banking immediately after graduating. That is, exogenous shocks affect the initial career choices of this sample. In the rest of the paper, I examine how long these shocks go on affecting the graduates and whether it has any effects on their incomes.

\section{$5 \quad$ Initial Conditions and Long-Term Outcomes}

\subsection{Persistence in Investment Banking}

Figure 3 provides an initial look at how first job after MBA graduation is related to jobs held later. The graph shows the fraction of each graduating class that initially takes a job in investment banking and then what fraction of the class works in banking for up to ten years after graduation. As the graph shows, classes where a relatively large set of people go into banking still have a high fraction in banking at any given year over this first post-graduation decade. For example, among those classes where there was a substantial drop in people entering investment banking in the late 1980's after the crash of 1987, representation on Wall Street remained low over the entire 


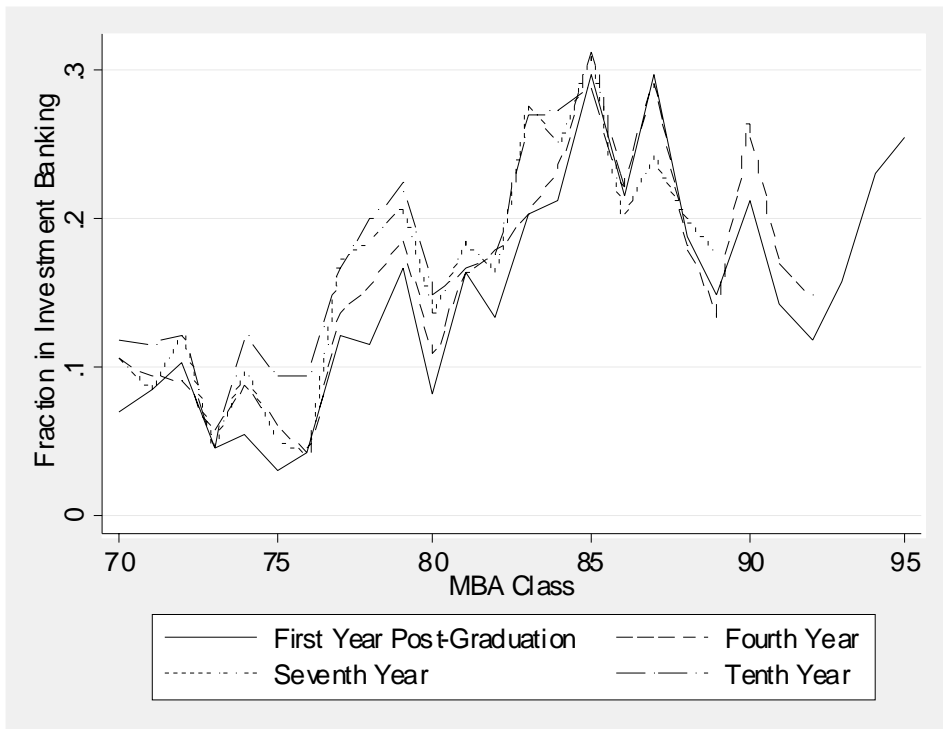

Figure 3: Fraction of Class in Investment Banking 1-10 Years After MBA

available sample. While this suggests that an exogenous shock has long-term effects on human capital investments and careers, I now consider this issue more formally.

I model MBA $i$ 's industry as of year $t$ by updating equation (1) to

$$
F_{i t}=G\left(\theta_{t}, X_{i t}, \Psi_{i}, F_{i}^{0}\right)
$$

where $F_{i}^{0}$ is an indicator for whether the person worked in investment banking in the first year after graduation. OLS or a simple logit will not reveal the causal effect of $F_{i}^{0}$ on $F_{i t}$ because an individual with an appropriate set of skills and/or tastes for a given industry will be more likely to both start in and eventually work in that industry.

However, to establish the basic relationship between initial and long-term investment bank employment that is predicted by all three models discussed in Section 2, I start by studying the relationships between long-term investment banking attachment, initial investment bank placement, and stock returns while in school. This provides a useful benchmark to compare with the IV estimates below and allows me to see how the basic relationship between initial and later employment $\left(F_{i}^{0}\right.$ and $\left.F_{i t}\right)$ varies with the state of the market at graduation $\left(\theta_{t}\right)$. I run OLS regressions where an observation is a person/year at least two and a half years after the person graduates from Stanford. The dependent variable is one if the person is an investment banker at the time of the observation and zero otherwise. Results are in Table 4. 


\begin{tabular}{lcccc}
\hline \hline & $(1)$ & $(2)$ & $(3)$ & $(4)$ \\
\hline Initially I-Bank & 0.7881 & 0.8072 & 0.7628 & 0.7764 \\
& $(0.0157)$ & $(0.0279)$ & $(0.0242)$ & $(0.0227)$ \\
I-Bank Pre-MBA & 0.0454 & 0.0607 & 0.0346 & 0.0257 \\
& $(0.0178)$ & $(0.0176)$ & $(0.0450)$ & $(0.0486)$ \\
State of Market at Graduation & All Years & Bull & Average & Bear \\
N (observations) & 49,920 & 21,087 & 10,641 & 18,192 \\
N (people) & 3,313 & 1,787 & 511 & 1,015 \\
\hline
\end{tabular}

Table 4: Industry of Longer-Term Job. All columns are results of linear probability regressions. The dependent variable, which is based on a person's job as of the end of January in a year at least two and a half years after graduation from Stanford GSB, equals one if the person works in investment banking (including money management or venture capital.) "Initially I-Bank" equals one if the person was working in investment banking in the January after graduation. "I-Bank Pre-MBA" equals one if the person worked in investment banking before studying at Stanford GSB. "Bull" market indicates the two-year average annual return of the S\&P 500 was greater than $13 \%$ while the person attended Stanford GSB. "Bear" market indicates annual return of less than 5\%. Each regression includes indicator variables for gender, Black, Hispanic, Asian, year of observation, and years since graduation. Standard errors (in parentheses) are adjusted for any correlation within a graduating class.

As expected, there is a strong relationship between $F_{i}^{0}$ and $F_{i t}$. The probability that a person who starts in investment banking will work there in a later year is about eighty percentage points higher than someone who starts elsewhere. Controlling for starting in investment banking after business school, the relationship between working in investment banking before business school and working there later is small.

I repeat the analysis dividing the sample into groups that were in school when returns were above the sample average (bull markets), when returns were below an approximation of the risk free rate (bear markets), and other years (average markets.) The most noteworthy result in Table 4 is the consistency of the relationship between starting in investment banking and working there later. Columns (2)-(4) show that the eighty percentage point difference holds no matter what the conditions of the market when the person graduated. To the extent that there is any difference at all, it appears that those who go to Wall Street during bull markets are the most attached while the sorting model would predict the opposite. Combined with the suggestive evidence on finance class enrollments in the last section, this indicates that there is no evidence that bull markets attract less qualified or less interested candidates.

I now estimate the causal effect of starting in investment banking $\left(F_{i}^{0}\right)$ on working there later $\left(F_{i t}\right)$ by using instruments for $F_{i}^{0}$. I use either the macro variables from column 5 of Table 3 or a set of indicator variables for each graduating class. The macroeconomic proxies for demand for 
new MBA's have the ideal features of valid instruments. The return on the S\&P 500 and the unemployment rate affect initial placement of MBA's, as shown in Table 3, but I see no reason they would affect where they work later except through the effect on initial placement.

As mentioned above, year indicators are more powerful instruments. If this is because the class indicators are more flexible and direct measures of demand for MBAs in a given year, then they constitute a valuable instrument. That is, if classes of Stanford MBAs are generally similar in skills and interests, at least controlling for pre-MBA industry, then the class indicators are valid instruments because they capture differences in career prospects and demand by employment sector. However, if there are important differences from year to year in the types of people admitted to Stanford, then this may not be a valid approach. The fact that all the MBA results are not generally sensitive to controlling for pre-MBA experience and that the results are generally similar (though less precisely estimated) when using stock return and unemployment as instruments is somewhat comforting, but it is still important to bear in mind the underlying assumptions when using the class indicators as instruments.

I also use the fraction of MBAs graduating from the University of Pennsylvania's Wharton School that went into investment banking as an instrument. This gets around some of the potential problems with using class indicators as instruments, while hopefully capturing supply and demand features of the MBA/investment bank match in a given year that are not captured by the macroeconomic variables. Unless Wharton and Stanford changed their admissions and recruiting policies in a similar way or the types of people that applied to top MBA programs changed systematically (neither of which is impossible), initial Wharton placement should be correlated with initial Stanford placement but not longer-term Stanford career choice. Because the Wharton information is only available after the class of 1973, the sample size is reduced when using this instrument.

Two-stage least squares (that is, linear probability with instrumental variables) estimates of equation (2) with instruments for $F_{i}^{0}$ are displayed in Table $5 .{ }^{11}$ Panel A uses the two S\&P returns and unemployment as instruments for first job after graduation. Column 1, which includes all available person/years, shows that a person who takes a job on Wall Street upon graduation has about a $50 \%$ higher probability of working on Wall Street in a later year than someone whose first job is elsewhere. Column 2 shows that controlling for pre-MBA experience makes the effect of initial Wall Street employment statistically insignificant, though the coefficient is also not statistically different from the coefficient in Column 1.

Columns 3 and 4 of Panel A show that the effect is more precisely estimated, and stronger, for

\footnotetext{
${ }^{11}$ The linear probability specification is relatively simple to implement and keeps the interpretation straight-forward. Angrist (2001) argues that linear probability is an appropriate empirical approach in contexts such as this.
} 


\begin{tabular}{|c|c|c|c|c|}
\hline Panel A: Macro & Instrum & $\overline{(2)}$ & $\overline{(3)}$ & $\overline{(4)}$ \\
\hline Initially I-Bank & $\begin{array}{c}0.4982 \\
(0.2411)\end{array}$ & $\begin{array}{c}0.4166 \\
(0.2879)\end{array}$ & $\begin{array}{c}0.3299 \\
(0.4402)\end{array}$ & $\begin{array}{c}0.7819 \\
(0.1400)\end{array}$ \\
\hline I-Bank Pre-MBA & & $\begin{array}{c}0.2081 \\
(0.1359)\end{array}$ & Dropped & $\begin{array}{l}\text { Others } \\
\text { Dropped }\end{array}$ \\
\hline $\begin{array}{l}\mathrm{N} \text { (observations) } \\
\mathrm{N} \text { (people) }\end{array}$ & $\begin{array}{c}49,920 \\
3,313\end{array}$ & $\begin{array}{c}49,920 \\
3,313\end{array}$ & $\begin{array}{c}47,860 \\
3,052\end{array}$ & $\begin{array}{c}2,060 \\
261\end{array}$ \\
\hline \multicolumn{5}{|c|}{ Panel B: Wharton and Macro Instruments } \\
\hline Initially I-Bank & $\begin{array}{c}0.8669 \\
(0.1164)\end{array}$ & $\begin{array}{c}0.8793 \\
(0.1348)\end{array}$ & $\begin{array}{c}0.9228 \\
(0.1913)\end{array}$ & $\begin{array}{c}0.8295 \\
(0.1146)\end{array}$ \\
\hline I-Bank Pre-MBA & & $\begin{array}{c}0.0295 \\
(0.0576)\end{array}$ & Dropped & $\begin{array}{l}\text { Others } \\
\text { Dropped }\end{array}$ \\
\hline $\begin{array}{l}\mathrm{N} \text { (observations) } \\
\mathrm{N} \text { (people) }\end{array}$ & $\begin{array}{c}18,658 \\
2,101 \\
\end{array}$ & $\begin{array}{c}18,658 \\
2,101 \\
\end{array}$ & $\begin{array}{c}17,229 \\
1,865 \\
\end{array}$ & $\begin{array}{c}1,429 \\
236 \\
\end{array}$ \\
\hline \multicolumn{5}{|c|}{ Panel C: Class Instruments } \\
\hline Initially I-Bank & $\begin{array}{c}0.7751 \\
(0.0777)\end{array}$ & $\begin{array}{c}0.7959 \\
(0.0771)\end{array}$ & $\begin{array}{c}0.8372 \\
(0.0941)\end{array}$ & $\begin{array}{c}0.9654 \\
(0.0537)\end{array}$ \\
\hline I-Bank Pre-MBA & & $\begin{array}{c}0.0420 \\
(0.0396)\end{array}$ & Dropped & $\begin{array}{l}\text { Others } \\
\text { Dropped }\end{array}$ \\
\hline $\mathrm{N}$ (observations) & 49,920 & 49,920 & 47,860 & 2,060 \\
\hline $\mathrm{N}$ (people) & 3,313 & 3,313 & 3,052 & 261 \\
\hline
\end{tabular}

Table 5: Industry of Longer-Term Job. All results are based on two-stage least squares linear probability regressions. The dependent variable, which is based on a person's job as of the end of January in a year at least two and a half years after graduation from Stanford GSB, equals one if the person works in investment banking (including money management or venture capital.) "Initially I-Bank" equals one if the person was working in investment banking in the January after graduation. "I-Bank Pre-MBA" equals one if the person worked in investment banking before studying at Stanford GSB. "Macro" instruments for "Initially I-Bank", which are all measured as of time of MBA graduation, are 1-year and 2-year S\&P return, and the national unemployment rate. "Class" instruments is a set of graduating year indicator variables. "Wharton" instrument is the fraction of new Wharton graduates that took investment banking jobs in the year the Stanford MBA graduated. It is only available for the class of 1975 and later, so the sample size is smaller. Standard errors (in parentheses) are adjusted for any correlation within a graduating class. 
those who worked on Wall Street before studying at Stanford than on the rest of the sample. For the pre-MBA Wall Street sample, returning to Wall Street right after going to Stanford makes the person $78 \%$ more likely to work there in any given later year. For the non-Wall Street pre-MBA sample, the estimated coefficient is still fairly large, but it is very imprecisely estimated. Overall, Panel A indicates that there is a strong causal effect of initial Wall Street employment on longerterm Wall Street employment and that this effect is focused on the subset of the class that worked on Wall Street before getting an MBA.

Panel B repeats the analysis adding the Wharton placement instrument for first jobs. This makes the estimates in Panel B more precise than those that use only the macroeconomic instruments. Though the coefficients are somewhat higher than in Panel A, the economic conclusions are unchanged. However, if Wharton placement is a valid instrument, the causal effect of initial investment bank employment on later investment bank employment is strongly significant for the sample as a whole and both subsamples. Finally, Panel $\mathrm{C}$ shows the results when using the class indicators as instruments. The coefficients and significance levels are very similar to the Panel B results.

Overall, Table 5 provides strong evidence that getting a job in investment banking has a strong causal effect of working in investment banking later among the subset of MBAs that has already shown an interest in working on Wall Street. The effect for the rest of the class ranges anywhere from zero to the same as for the pre-MBA investment bankers, depending on one's confidence in using Wharton's placement or the class indicator variables to instrument for taking an initial Wall Street job.

While Table 5 makes it clear that initial placement in investment banking is sticky, the effects in the table are averaged over all career years for the sample. To see how this effect varies over time, I ran a series of IV regressions similar to those in column 1 of Table 5 with each regression limiting the sample to person/years a specific number of years after graduation. Figure 4 graphs the IV coefficient on the "Initially I-Bank" variable for each year. For example, when running the same regression as in Column 1 of Panel A of Table 5, but limiting the sample to person/year observations as of the fourth January after a given person receives his MBA, the coefficient is 0.726 and the $95 \%$ confidence interval for this coefficient spans from 0.488 to 0.963 . Given the nature of the sample, the sample size gets smaller as the number of years since graduation increases. Therefore, the estimates get less precise moving to the right on the Figure. However, the figure makes clear that, for the first decade or more after graduation, those who go from Stanford to Wall Street are much more likely to work there than those who start in another industry. The coefficients for years 


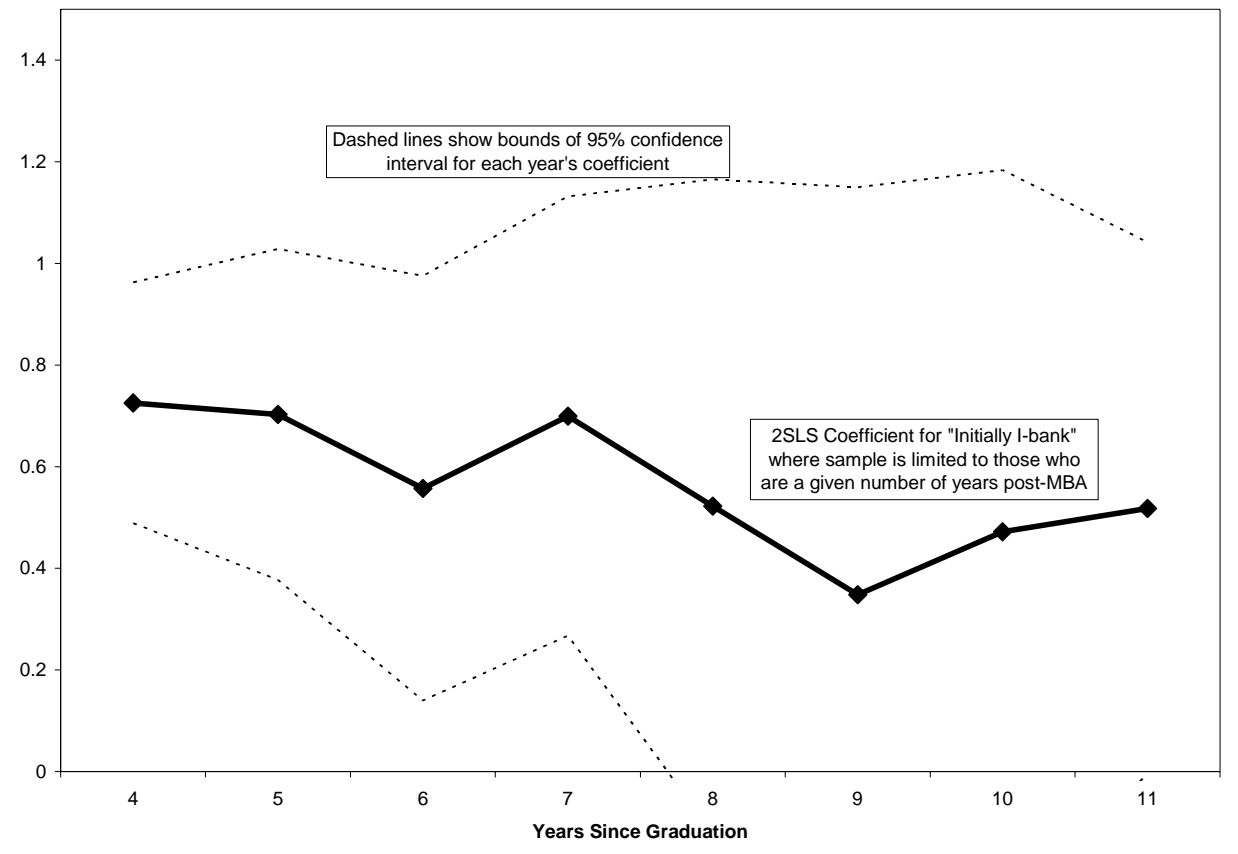

Figure 4: Year-by-Year IV Estimates of Effect of Initial I-Bank Placement on I-Bank Employment

twelve and higher are quite similar (all are at least 0.4 and most are near one), but noisy. ${ }^{12}$

The overall message from Tables 3 and 5, as well as Figure 4, is clear. Stock market returns while Stanford MBAs are in school have an important effect on whether or not many of them go from Stanford to a job on Wall Street. If they do go to Wall Street, even for "random" reasons driven by stock market conditions, they are much more likely to work there at any given point later in their careers than if they do not go to Wall Street. While people move in and out of investment banking after they enter the labor force, where they start matters a great deal. It appears that this effect is stronger for those most likely to be interested in working on Wall Street (that is, those who worked there before going to Stanford.)

\subsection{Interpretation}

The key empirical results so far can be summarized as follows. High stock returns while an MBA is in school have a sizeable effect on the likelihood that the MBA will go to Wall Street upon graduation. MBAs who start their career on Wall Street are more likely to work there later on.

\footnotetext{
${ }^{12}$ Graphs similar to Figure 4, but based on regressions with Wharton placement or class indicators as instruments, generally have coefficients that are closer to one and precisely estimated.
} 
This relationship does not vary with the state of the market at graduation, so those who go to Wall Street during bull markets are not less attached to Wall Street than those who go during bear markets. The relationship is causal, in that those who go to Wall Street right after graduation are more likely to work there later because they started their careers on Wall Street. The relationship is particularly strong (or at least particularly precisely estimated) for those who have already shown an interest in finance by working on Wall Street before pursuing an MBA.

The combination of these results suggests that the pool of potential investment bankers in a typical Stanford MBA is relatively homogeneous and that those who go to Wall Street make important finance-specific investments. That is, the patterns in the data most closely match "Model 2" presented in Section 2. The data are consistent with a labor market where a large number of Stanford MBAs could be successful investment bankers, Wall Street firms demand more people when the stock market is doing well, and the wage difference between investment banking and other jobs is a compensating differential that roughly offsets the unpleasant parts of being an investment banker. This would explain the findings that the relationship between initially working on Wall Street and working there later is not dependent on the state of the stock market when MBAs graduate and that MBAs who go to Wall Street during bull markets are no less interested or successful in finance-related MBA classes than those who go during bear markets. That is, I found no evidence that the lucrative offers during bull markets attract those who are less able or less interested in investment banking to start their careers on Wall Street.

Given the causal relationship between initial Wall Street jobs and long-term Wall Street jobs, the patterns in the data also indicate that Stanford MBAs build up significant "task-specific human capital" (as in Gibbons and Waldman (2006)) while in school and very quickly after leaving school. That is, people who go to school during bull markets invest in finance classes at Stanford and in valuable on-the-job training shortly after graduation. This increases the wage differential they enjoy in banking relative to other fields and may also lower some of the disutility of investment banking work. This model is supported by the informal analysis of classes discussed in Section 4 . It appears that students who were at Stanford during bull markets built finance-specific human capital that got them started in finance careers. The long-term career results in Section 5 suggest that they continued building finance-related human capital upon starting work on Wall Street.

The fact that first jobs are so closely related to macroeconomic conditions appears, at first inspection, to also be consistent with a simple signaling story ("Model 1" in Section 2.) In that model, there are two types of people (bankers and non-bankers) that are interested in starting their careers in investment banking - one because they are good at the work and one because they like the money. Bear markets separate the two types during the job application process while bull 
markets force investment banks to sort between the two types after hiring them. This model would imply that stickiness in banking should be stronger for new MBAs hired in lean times, rather than in good times. In an extreme form where there are only two types of MBAs, there would be no causal effect of first jobs in banking on later employment in that sector. It also implies that those MBAs who go to Wall Street when times are good should be less interested in finance, which might show up by their taking fewer finance classes at Stanford. Given that there is a causal link between first jobs on Wall Street and later jobs there, that stickiness in banking is not related to conditions when MBAs are in school, and that the larger group that goes to Wall Street during bull markets takes more finance classes, this model is not consistent with the data.

The findings are also not consistent with a hybrid model ("Model 3" in Section 2) where investment banks value finance-specific investments but also focus on MBAs who are most suited to work on Wall Street. As I discussed above, such a model would lead to a causal link between initial Wall Street jobs and later Wall Street employment. However, it would also lead to the average Wall Street hire during bull markets being less interested and attached to banking than the average bear market hire. This is simply not consistent with the findings. So, while there is surely some heterogeneity in a typical Stanford MBA class in how well they fit in investment banking, there appears to be a sufficient supply of those who are able and interested in the field to meet the banks' demand without compromising significantly in terms of "fit."

It appears that a different form of sorting and hybrid model may explain the patterns in the data. The data are consistent with the following slightly more specific version of "Model 2." Suppose there are two types of MBAs - those who have an interest in finance and those who do not. The finance-disposed group is largely indifferent between finance and other opportunities when starting their careers. Given sufficiently strong beliefs about Wall Street conditions, they will start their careers in finance and they will make finance-specific investments while at Stanford and shortly thereafter. This group of homogeneous MBAs includes those who worked in finance before getting MBAs and some unobservable subset of the rest of the class. This variant of the model with homogeneous workers that make finance-specific investments is consistent with all the findings above, including the fact that all results are somewhat stronger for those who worked in finance before getting MBAs. 


\section{Measuring The Financial Impact}

\subsection{What Would They Do if Not Investment Banking?}

Stock market conditions at graduation lead to careers on Wall Street. But, in order to estimate the financial ramifications of this effect, I need to make assumptions about what these people would have done if they had not gone to work on Wall Street. I address that issue in this section by looking at the effect of initial placement in investment banking on the probability of working in other industries in the longer term. To do this, I change equation (2) to

$$
T_{i t}=G\left(\theta_{t}, X_{i t}, \Psi_{i}, F_{i}^{0}\right)
$$

where $T_{i t}$ is an indicator for whether the person works in some other industry in year $t$. By the same logic as in the last section, I cannot use OLS or a standard logit to estimate (3) because unobserved ability and taste factors $(\Psi)$ are likely to be correlated with whether the person first goes to Wall Street and whether or not he works in another industry later on. I therefore use the same instruments as in the last section.

Table 6 displays results where $T$ is an indicator for being an entrepreneur (that is, working at a firm that he founded) or working in the management consulting industry. I should note that the results here need to be interpreted cautiously because these are the two outcome variables where I found a relationship with initially being an investment banker. I found no such relationship for working in high technology or working for a large manufacturing firm. One interpretation of this is that the "additional" investment bankers were more likely to become entrepreneurs or consultants than to work in these other areas. But another possibility is that, by looking at a bunch of possible outcomes, some are likely to appear to have a significant relationship with initial investment banking placement. While I therefore prefer to cautiously interpret the evidence here as only suggestive, choosing between these interpretations will be important when analyzing the effects of initial job on income in the next section.

Columns 1 and 2 show that there is some evidence that initial jobs on Wall Street lead GSB graduates to start fewer businesses. The coefficients are strongly negative for both sets of instruments, but only significantly so with the class indicators. If the class indicators are valid instruments, it suggests that starting in investment banking lowers the probability of being an entrepreneur by about $22 \%$. The consulting estimates (columns 3 and 4 ) are somewhat more consistent across the two specifications and the estimates are of a similar magnitude to the entrepreneur estimates. Overall, Table 6 provides suggestive evidence that the Wall Street careers generated by stock returns while students attend Stanford come at the expense of careers as consultants and as entrepreneurs. 


\begin{tabular}{lcccc}
\hline \hline Dependent Variable & $\begin{array}{c}\text { Founder } \\
(1)\end{array}$ & $\begin{array}{c}\text { Founder } \\
(2)\end{array}$ & $\begin{array}{c}\text { Consultant } \\
(3)\end{array}$ & $\begin{array}{c}\text { Consultant } \\
(4)\end{array}$ \\
\hline Initially I-Bank & -0.6313 & -0.2150 & -0.3162 & -0.2641 \\
& $(0.6047)$ & $(0.0970)$ & $(0.4961)$ & $(0.1163)$ \\
Instruments & Macro & Class & Macro & Class \\
\hline
\end{tabular}

Table 6: Industry of Longer-Term Job. All columns are results of two-stage least squares linear probability regressions. Observations are based on a person's job as of the end of January at least two and a half years after graduation from Stanford GSB. "Initially I-Bank" equals one if the person was working in investment banking (including money management or venture capital) in the January after graduation. "Founder" equals one if the person founded the company where he/she works at the time of the observation. "Consult" equals one if the person works for a management consulting firm. "Macro" instruments for "Initially I-Bank", which are all measured as of time of MBA graduation, are 1-year and 2-year S\&P return, and the national unemployment rate, while "class" instruments is a set of graduating year indicator variables. Each regression includes 49,920 observations from 3,313 different people. Standard errors (in parentheses) are adjusted for any correlation within a graduating class.

\subsection{How Much Wealth is Transferred by Initial Conditions?}

I now turn to the question of how much money is involved in the random movement of MBAs in and out of investment banking careers. As mentioned above, the data are not perfect for this purpose. Because people only report beginning and ending salary for each job, I cannot directly estimate the effects on an individual of starting on Wall Street by fitting wage regression equivalents of equation (2). However, because respondents provided income information as of the date of the survey, I can use this cross-section to estimate wage profiles in investment banking and other fields over the course of MBA careers. I then discount these profiles over various career lengths to estimate the lifetime labor income gained by those who become investment bankers.

I first break the sample into four sectors - investment bankers, consultants, entrepreneurs (those who founded a non-investment-banking business at which they work), and other. I also divide the sample into groups based on the number of years since graduation at the time of the survey. Combining these divisions, I create sector/years-since-graduation cells and calculate the average wage in each cell. Each sector's average wages for years one through fifteen after graduation are displayed in Figure $5 .{ }^{13}$ Two clear patterns emerge. First, investment bankers earn a substantial premium to the other groups throughout the first fifteen years after graduation. Second, management consultants

\footnotetext{
${ }^{13}$ The average wage in each cell is estimated imprecisely because of the small numbers of people in some categories. To smooth out some of this imprecision, the graph actually plots, for each cell, the average salary for that cell, the cell from the same sector with one more year since graduation, and the cell from the same sector with one fewer year since graduation. For the first year, I average the cell and the second year cell.
} 


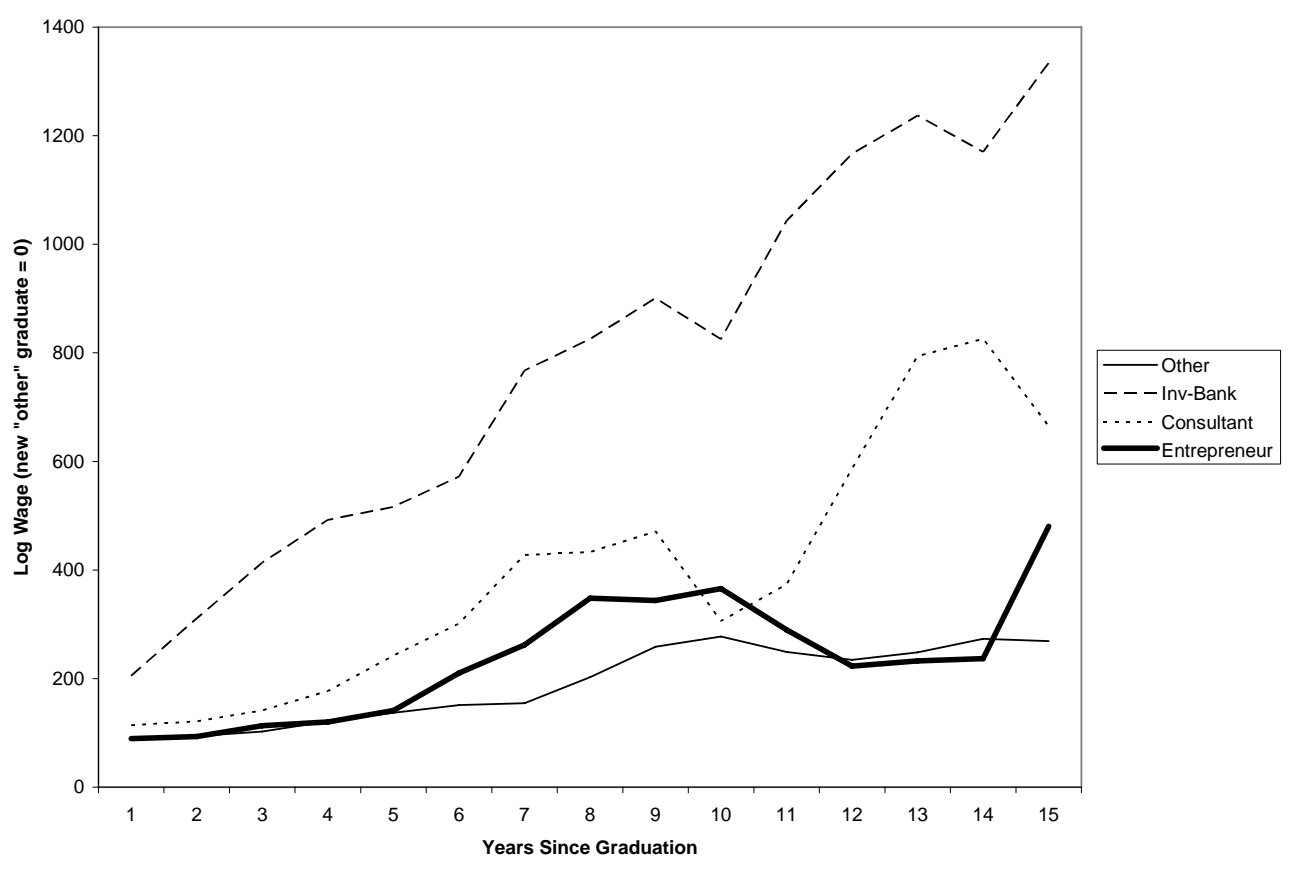

Figure 5: Career Wage Profiles by Type of Job

earn a premium over others, but not as much as investment bankers.

The income difference that I want to calculate, however, is not the simple difference between an investment banker at a given point in his career and someone at a similar point in a career in another field. I want to estimate the effect of starting in investment banking. Therefore, I calculate the expected income in career year $t$ for a person who starts his career in investment banking as

$$
E\left(w_{F_{0} t}\right)=\operatorname{Pr}\left(F_{t} \mid F_{0}\right) w_{F t}+\left(1-\operatorname{Pr}\left(F_{t} \mid F_{0}\right)\right) w_{G t}
$$

where $w_{F t}$ and $w_{G t}$ are expected income in career year $t$ in investment banking and an alternative job, respectively, and $\operatorname{Pr}\left(F_{t} \mid F_{0}\right)$ is the probability the person will be in investment banking in year $t$, conditional on starting in investment banking. $\operatorname{Pr}\left(F_{t} \mid F_{0}\right)$ for a given $t$ is the yearly coefficient from estimating equation (2), as displayed in Figure 4.

To summarize the underlying logic, I generate expected year-by-year income levels for MBAs who become management consultants, entrepreneurs, or any other non-investment-banker based on the cross-section of wages as of the time of the survey. I generate expected year-by-year income levels for MBAs that start as investment bankers by taking the weighted average of the investment banker income and income in the other jobs. The weights for this calculation are based on the estimated 


\begin{tabular}{|c|c|c|c|}
\hline & (1) & $(2)$ & (3) \\
\hline Alternative Job & Other & Consult & Entrepreneur \\
\hline \multicolumn{4}{|l|}{ Wage Difference Estimates: } \\
\hline Year 1 Wage Diff. (\$000) & $\$ 97.5$ & $\$ 71.2$ & $\$ 114.9$ \\
\hline Year 1 Wage Diff. (\%) & $115.4 \%$ & $64.3 \%$ & $170.1 \%$ \\
\hline Year 7 Wage Diff. $(\$ 000)$ & $\$ 504.0$ & $\$ 308.1$ & $\$ 321.6$ \\
\hline Year 7 Wage Diff. (\%) & $331.6 \%$ & $88.6 \%$ & $96.2 \%$ \\
\hline Year 15 Wage Diff. (\$000) & $\$ 937.2$ & $\$ 578.4$ & $\$ 1,014.5$ \\
\hline Year 15 Wage Diff. (\%) & $327.4 \%$ & $89.7 \%$ & $485.6 \%$ \\
\hline \multicolumn{4}{|c|}{ Lifetime Income Difference Estimates (Discount Rate $=5 \%$ ): } \\
\hline 10 Year Difference $(\$ 000)$ & $\$ 2,095$ & $\$ 1,176$ & $\$ 1,774$ \\
\hline 10 Year Difference $(\%)$ & $169.1 \%$ & $54.5 \%$ & $113.8 \%$ \\
\hline 20 Year Difference $(\$ 000)$ & $\$ 4,895$ & $\$ 2,508$ & $\$ 4,195$ \\
\hline 20 Year Difference $(\%)$ & $196.0 \%$ & $51.3 \%$ & $131.1 \%$ \\
\hline \multicolumn{4}{|c|}{ Lifetime Income Difference Estimates (Discount Rate $=10 \%$ ): } \\
\hline 10 Year Difference $(\$ 000)$ & $\$ 1,704$ & $\$ 1,000$ & $\$ 1,471$ \\
\hline 10 Year Difference $(\%)$ & $174.5 \%$ & $59.5 \%$ & $121.6 \%$ \\
\hline 20 Year Difference $(\$ 000)$ & $\$ 3,177$ & $\$ 1,689$ & $\$ 2,754$ \\
\hline 20 Year Difference $(\%)$ & $194.8 \%$ & $54.1 \%$ & $134.2 \%$ \\
\hline
\end{tabular}

Table 7: Income Differences Between Investment Bankers and Others. All calculations are based on salary averages for sector and years since graduation from the cross-section of 2,598 survey respondents. Investment banker wage estimates are adjusted for the likelihood that they will still be investment bankers at each year after graduation. See text for details.

causal effect of still being an investment banker in year $t$ if the person went into investment banking right after getting his MBA at Stanford.

Based on this process for estimating experience/wage profiles in each of the four types of jobs, Table 7 presents estimates of the pay differences between investment banking and other jobs at various points in a person's career. It also shows the cumulative present value of the income difference between investment banking and other jobs over the first ten and twenty years after graduation, assuming either a $5 \%$ or $10 \%$ discount rate on future income. While the wage difference between fields and over a career profile will surely change over time, these estimates are what a new graduate might expect in 1996 looking forward.

The first few rows of Table 7 show the individual year expected wage differences between someone who starts as an investment banker and someone who works continuously in one of the other areas. These estimates vary from a $64 \%$ difference between investment bankers and consultants right after graduation to cases where the investment banker can expect to earn three to six times what people in the other groups can expect. For example, members of the "other" category earn an average of $\$ 286 \mathrm{~K}$ after fifteen years while someone who starts as an investment banker can expect to earn $\$ 1.2$ million at that point. At this same point, investment bankers can expect to earn almost 
double the $\$ 645 \mathrm{~K}$ earned by management consultants.

Discounting these figures over a ten or twenty year career leads to substantial absolute income differences for investment bankers relative to other fields. The smallest estimate of the investment banker premium is about $50 \%$ (for an investment banker who otherwise would have been a consultant and considers a twenty-year horizon.) The difference between investment bankers and others is at least $150 \%$ and can reach several million dollars in present value. Relative to entrepreneurs, the differences are up to $\$ 5$ million in present value over twenty years. These estimates suggest that substantial amounts of wealth, both in absolute dollars and as a percentage of lifetime earnings, can be moved from or to a given MBA by uncontrollable macroeconomic factors while people attend business school.

As a final calculation, I consider how much total discounted lifetime income one whole class of MBAs can expect to earn relative to another based solely on stock return differences while they attend school. A one standard deviation change in the two-year return of the S\&P 500 is associated with two percent more of the class entering investment banking. A typical Stanford class has 350 students, so two percent is seven extra students going to Wall Street. Given the estimates in Table 7, this suggests stock returns during school lead one class to have between $\$ 12$ million and $\$ 35$ million more discounted lifetime earnings than the other class in the first twenty years after graduation. Consider the more stark example of the classes of 1986 and 1987 (which graduated before the crash of 1987) compared to the classes of 1988 and 1989. Year fixed-effect logits similar to the ones displayed in Table 3 suggest the pre-crash group had a $7.3 \%$ higher probability of working on Wall Street immediately after graduation. This means that about fifty more members of the two pre-crash classes started on Wall Street than the post-crash classes which means these classes earned an extra $\$ 85$ million to $\$ 250$ million over the first twenty years after graduation.

One concern that naturally arises from this back-of-the-envelope approach to estimating lifetime effects is whether the underlying assumptions and numbers are valid. The fact that the income measure is "salary" rather than total wealth created in a year is of particular concern. However, if anything, I would expect this to mean that the income premium for investment bankers in Table 7 is biased downward because so much investment banking income comes through bonuses. The one exception to this might be the comparison with entrepreneurs who are often earning substantial wealth through building equity that they would not report as salary. Another potential problem is that the income measure is categorical rather than exact. However, this concern is largely alleviated by the fact that the averages I calculate are consistent with the information provided by the career office based on their exit surveys.

While the estimates in the last section are no doubt measured with some (perhaps considerable) 
error, they provide substantial evidence that Wall Street conditions at graduation affect many MBAs' jobs and income for a long time after graduation. In combination with the earlier results, they suggest that the compensating differential to induce an MBA to become an investment banker is quite large.

\section{Conclusions}

Stock price movements can create and destroy a lot of wealth among investors. In this paper, I have shown that they can also create or destroy a lot of future labor market income for people earning MBAs at Stanford. Bull markets encourage new graduates to start their career on Wall Street. Initially working on Wall Street has a strong causal effect on the likelihood of working there later in an MBA's career. Because investment bankers earn a substantial premium relative to other MBA jobs, any effect on initial job placement has a substantial and long-term effect on many MBAs' income. The results suggest that the large premium for working on Wall Street is a compensating differential that makes many new MBAs nearly indifferent between jobs on Wall Street and elsewhere and that bull markets lead MBA students and recent graduates to develop significant finance-specific human capital. Further research is required to be more precise about what causes this career stickiness and better data would help more accurately measure the effect on career labor income.

The results also suggest that risk averse MBA students, especially those interested in Wall Street careers, may want to take actions to insure themselves against the random wealth effects imposed by stock returns while they study. These students should short the stock market upon entering school so that their portfolios hedge their expected labor income. 


\section{References}

Akerlof, George A., "The Market for Lemons: Quality Uncertainty and the Market Mechanism," Quarterly Journal of Economics, 1970, 109, 701-733.

Angrist, Joshua D., "Estimation of Limited Dependent Variable Models With Dummy Endogenous Regressors: Simple Strategies for Empirical Practice," Journal of Business and Economics Statistics, 2001, $19,2-28$.

Baker, George, Michael Gibbs, and Bengt Holmstrom, "The Internal Economics of the Firm: Evidence from Personnel Data," Quarterly Journal of Economics, 1994, 109, 881-919.

Beaudry, Paul and John DiNardo, "The Effect of Implicit Contracts on the Movement of Wages Over the Business Cycle: Evidence from Micro Data,” Journal of Political Economy, 1991, 99, 665-688.

Benartzi, Shlomo, "Excessive Extrapolation and the Allocation of 401(K) Accounts to Company Stock," Journal of Finance, 2001, 56, 1747-1764.

Brown, Keith C., W. V. Harlow, and Laura T. Starks, "Of Tournaments and Temptations: An Analysis of Managerial Incentives in the Mutual Fund Industry," Journal of Finance, 1996, 51, 85-110.

Brown, Virginia P., "An M.B.A. Runs the Gauntlet," New York Times, 1988, p. BW22. June 12.

Chen, Hsuan-Chi and Jay R. Ritter, "The Seven Percent Solution," Journal of Finance, 1995, 55, $1105-1131$.

Chevalier, Judith A. and Glenn Ellison, "Risk-Taking by Mutual Funds as a Response to Incentives," Journal of Political Economy, 1997, 110, 1167-1200.

Chevalier, Judith and Glenn Ellison, "Career Concerns of Mutual Fund Managers," Quarterly Journal of Economics, 1999, 114, 389-432.

Devereaux, Paul, "The Benefits of Obtaining a High-Paying Job," 2004. UCLA.

Gibbons, Robert and Michael Waldman, "Enriching a Theory of Wage and Promotion Dynamics Inside Firms," Journal of Labor Economics, 2006, 24, 59-107.

Gompers, Paul and Joshua Lerner, "An Analysis of Compensation in the U.S. Venture Capital Parternship," Journal of Financial Economics, 1999, 51, 3-44.

Hvide, Hans K., "Firm Size and the Quality of Entrepreneurs," 2005. Norwegian School of Economics and Business.

Jovanovic, Boyan, "Job Matching and the Theory of Turnover," Journal of Political Economy, 1979, 87, 972-990.

Kahn, Lisa B., "The Long-Term Market Consequences of Graduation College in a Bad Economy," 2005. Harvard University.

Lazear, Edward P., "Entrepreneurship," Journal of Labor Economics, 2005, 23, 649-680. 
Lin, Hsiou-Wei and Maureen F. McNichols, "Underwriting Relationships, AnalystsŠ Earnings Forecasts and Investment Recommendations," Journal of Accounting and Economics, 1998, 25, 101-127.

McCall, Brian P., "Occupational Matching: A Test of Sorts," Journal of Political Economy, 1990, 98, 45-69.

Michaely, Roni and Kent L. Womack, "Conflict of Interest and the Credibility of Underwriter Analyst Recommendations," Review of Financial Studies, 1999, 12, 653-686.

Miller, Robert A., "Job Matching and Occupational Choice," Journal of Political Economy, 1984, 92, $1086-1120$.

Neal, Derek, "Industry-Specific Human Capital: Evidence from Displaced Workers," Journal of Labor Economics, 1995, 13, 653-677.

Oreopoulos, Philip, Till von Wachter, and Andrew Heisz, "Permanent and Transitory Effects from Graduating in a Recession," 2005. University of Toronto.

Oyer, Paul, "The Macro-Foundations of Microeconomics: Initial Labor Market Conditions and Long-Term Outcomes for Economists," 2005. Stanford Graduate School of Business.

Parent, Daniel, "Industry-Specific Capital and the Wage Profile: Evidence from the National Longitudinal Survey of Youth and the Panel Study of Income Dynamics," Journal of Labor Economics, 2000, 18, 306-323.

Reder, Melvin W., "An Analysis of a Small, Closely Observed Labor Market: Starting Salaries for University of Chicago M.B.A.s," Journal of Business, 1978, 51, 263-297.

Spence, Michael, "Job market signaling," Quarterly Journal of Economics, 1973, 87, 355-374.

Stewart, James, "Taking the Dare," The New Yorker, 1993, pp. 34-39. July 26.

Tracy, Joseph and Joel Waldfogel, "The Best Business Schools: A Market-Based Approach," Journal of Business, 1997, 70, 1-31.

Waldman, Michael, "Job Assignments, Signaling, and Efficiency," RAND Journal of Economics, 1984, $15,255-267$. 